\title{
Generic Studies: Their Renewed Importance in Religious and Literary Interpretation
}

\author{
Mary Gerhart
}

\begin{abstract}
In recent years, the need for a critique of "reader" as rigorous as that which has been developed for "text" and for "author" has become increasingly acute. Whether in the study of religion as story and biography or in interpretative reading in general, a critical notion of reader is essential if the act of reading is to be anything other than mere consumption of texts. Some new way of understanding the hermeneutıcal circle is required to avert the narcissism latent in the Anselmian model.

The notion of "genre" as developed by four recent theorists is helpful in the task of constructing a critique of "reader." E. D. Hirsch, Hans-Georg Gadamer, Tzvetán Todorov, and Paul Rucoeur have each surpassed the idealist notion of genre as a classificatory device and developed in its place the notion of genre as a generative pinciple.

Todorov, for example, illustrates how "form" is a theoretical, as distinct from a descriptive or explanatory, issue According to both Hirsch and Todorov, somewhere between empirical detalls and metaphysical thematizatıons lie generic formulations which can assist the reader to organize his/her response to the text and to recognize the probable understanding toward which the conventions of the text are directed.

In Gadamer's theory of interpretation, the notion of genre acquires historicity. After Gadamer, genres can no longer be regarded as tımeless $a$ priort categories Rather, because they are constituted by historical reflections, their rise and declıne are intrinsic to text-ınterpretatıon.

Finally, in Ricoeur's theory that generic considerations are correlative principles of production and interpretation, we find a basis for understanding genre as praxis. If we understand reading to be isomorphic to authoring, it becomes clear that the reader can no longer be regarded as the self-evident recipient of text-signification. Genre, in Ricoeur's theory, transforms
\end{abstract}

Mary Gerhart (Ph.D University of Chicago) is Assistant Professor of Religious Studies at Hobart and William Smith Colleges, Geneva, New York. She is a coeditor of Religious Studies Review and has published articles in The Journal of Religion, The Thomist, and Renascence. 
"speech" into a "work" and points toward a new notion of "reader" as one whose reconstruction of the text is the condition for the possibility of its being a story that "gives life."

This notion of "reader" makes possible a new model of the hermeneutical circle-one which signifies the essential roles of critical thought which follows naive reading and of informed understanding which follows after thought

\title{
Introduction: Need for a Critique of "Reader"
}

T N William Faulkner's Light in August, the main character, Reverend Hight ower, undergoes a major transformation when he delivers Lena Grove's child. Formerly addicted to introspection and reclusiveness, he becomes converted to action, having become a true believer in fecundity. This change is signified by his giving up reading Tennyson and turning instead to Shakespeare's Henry IV. Shakespeare, he says, is "food for a man"-ostensibly, of course, for the man he now is.

Murray Krieger uses this example in his recently published Theory of Crtticism to suggest that a reader, like Hightower, is disposed to remain entrapped in the process of his/her own experiencing. "This reference to literature as "food," Krieger says, "suggests clearly enough the notion that a reader matches his literary work to his prior needs, and then absorbs it into himself, forcing it to serve his own bodily functions."

Krieger reformulates this example into a critical issue:

\begin{abstract}
Are the literary works we read our teachers, shapers of our visions and our persons, or are they reflections of our needs? Do they seize upon us and mold us, creating for us and in us the forms that become the forms of all our imaginations, or do we seize upon them to be what our per sons require them to be, puttıng them into a rude service for us? Are we doomed only to project our own imaginative forms outward, peopling all works with the single cast of monsters created by our own imagination, and so turnıng all works into essentıally the same work, even though we persuade ourselves we are but responding to a variety of external features whose uniformity of pattern seems to confirm our hypothesis about them? In his hermeneutic circularity does the critic's every claım to objectivity reduce to this charade played out by his own personality in order to deceive - most of all-himself? (43-44)
\end{abstract}

This is not a new question. But perhaps it gains urgency in this time when story in and of itself has come to the fore in a remarkable relationship with relıgious studies. From John Dunne's bıographical approach to story, through Michael Novak's utilization of story as voyage, to explicit attempts to show how thinkıng is informed by story by Stephen Crites, Giles Gunn, 
William Doty, and James Hillman in James Wiggins's Religion as Story, the power of the metaphor of story for religious studies is manifest. Many studies of story and religion have burgeoned within recent years and most have been critical at the very least in the sense that they assume there are, as Carol Christ says, "Stories That Kill and Stories That Give Life." Some studies have more directly placed the critical element in the act of appropriation. Regardless of how the issue is articulated, from Philip Rieff's premise that a book is dead until a reader gives it voice to Walter Slatoff's plea for "respect for the reader," the critical reader is generally conceded to be the prime mover in a literary transaction.

This is not to say, however, that the new found affinity between story and religion is by virtue of its recent success immune to Krieger's suspicion that the reader-critic may be indulging in self-deception. And if Krieger's way of posing the problem is too general, Christopher Lasch levels a more specific indictment. Lasch describes the "new narcissism" of our time and designates the "retreat to purely personal satisfactions" as one major characteristic of the seventies: "To live for the moment is the prevailing passion-to live for yourself, not for your predecessors or posterity. We are fast losing the sense of historical continuity, the sense of belonging to a succession of generations originating in the past and stretching into the future" (5).

By calling attention to perversions of the act of reading, Krieger and Lasch assist in the task of making explicit the principles operative in a reader's critical appropriation of stories. On the one hand, they serve to dismiss the all too easy counter-criticism that the growing emphasis on reader aggrandizes the tendency toward self-absorption and narcissism. The focus on reader in their critiques makes self-evident, and, in a sense, forces those larger contexts of criticism which tend otherwise to remain so formal to permit, if not to foster, narcissism. Although nelther treat the issue of genre, thesr concerns are clearly related to generic / 1 / considerations. At the name time, however, they implicitly demand a more sophisticated model of the hermeneutical circle / 2 / (see Figure 1). This demand can be clarified by a pair of optical allusions. Krieger, for example, is skeptical of the reader's ability to transcend what seems to Krieger to be a viciousness of the hermeneutical circle (see Figure 2), and Lasch's notion of narcissism suggests that the text is a mirror surface from which only the reader's self-image is reflected (see Figure 3).

Initially, then, we wish to inquire how generic studies might provide one way of emending the confines of the circle (in response to Krieger) and of retrieving for the reader a sense of historical continuity (in response to Lasch), without allowing the reader to retreat into historicism. More generally, we will ask how generic studies might contribute to the task of developing a critique of "reader" as rigorous as that which has been developed in recent years for "text" and for "author." Our ambition here will be to show how the notion of "genre"-as reviewed by such theorists as E. D. Hirsch, Hans-Georg Gadamer, Tzvetán Todorov, and Paul Ricoeur-can function as a limitconcept for the notion of "reader" and ultimately for that of selfunderstanding. 


\section{Some Recent Theories of Genre}

The new view that genre is more than a principle of classification is a relatively recent development. The Princeton Encyclopedia of Poetry and Poctics, as late as 1965 , reflects the breakdown of the classical view of genre that has taken place in the last fifty years. Tracing the career of the word "genre" from the time of Plato and Aristotle, G. N. G. Orsini cites the exclusion of the lyric from almost all pre-nineteenth century studies of genre as an example of the fickleness of generic classification. Orsini's conclusion echoes the death knell for genre as a viable concept in criticism: "The most radical rejection of genre in modern times was made by Croce, who considered them mere abstractions, useful in the construction of classifications for practical convenience, but of no value as aesthetic categories" (308). Orsini models his notion of generic typification upon the rudimentary kind of scientific classification and blames nineteenth century philosophy for the prolongation of what he regards as futile categorizıng: "It can be imagined to what a riot of dialectic it led in Hegel's Aesthetic, which should have been a warning, but acted instead as an incentive to the metaphysical aestheticians of the nineteenth century, each with his own system of the arts and of the genre" (308). Clearly, for Orsini and, I imagine, for most readers of this influential handbook on literary theory, genre is defunct.

Each of the four following theorists, like Orsini, rejects the notion of genre as mere classification. Either they assimilate classification within other more essential functions of genre (Hirsch-determination of meaning; Todorov-relation of single texts to others), or they attempt to go beneath classification to some larger or more fundamental dimension of the task of defining genre (Gadamer-history; Ricoeur-production of text).

\section{E. D Hırsch-Genre as Constitutive Element in Interpretation}

Of the four, Hursch's theory appears to be the most radical. For him, there Is no meaning without genre; that is, verbal meaning is always "genre-bound" (76). In his most systematic treatment of the subject, he distinguishes between "intrinsic genre" and "broad genre." Intrinsic genre is a "shared type that constitutes and determines meanings," and its locus is somewhere between "broad or traditional genre" and the particular meaning of a literary work (7879). Genre is entirely on the side of interpretation: the need of generic considerations for developing a relatively stable norm of language is best seen, Hırsch thinks, when we have misinterpreted a work. For then the reader's faulty notion of genre, which governs his/her expectations of the particular meanings of a work, comes to be noticed. These expectations include the range of vocabulary and syntax, the tone of the work, the extension or rejection of particular connotations, and the explication of the relationship between the persona and the reader. When these expectations are frustrated or when the results of shaping them in a certain way are jumbled, we become aware that we have been working with a faulty generic conception. 
A good example of a text which requires almost all its readers to experience the need to change their generic expectations is Jonathan Swift's $A$ Modest Proposal. In his excellent analysis of how irony functions as the essential structure of this text, Wayne Booth notes that Swift's essay is designed to "deceive all readers for a time" and then require them "to recognize and cope with their deception":

Different readers will become suspicious at different points. . . But most will have had their suspicions fully aroused by paragraph 7 , and every reader should know, by paragraph 9 , that the most wrenching kind of irony is at work. Every reader has thus to some degree been duped-not simply for a fleeting moment of shock and reconstruction that is produced by essays that are ironic from the first word, but for sevelai par agiapis. And every reacier hids thus been cirawn into an engagement of the most active kind: having been driven to suspect, and finally to admit that the voice is speaking a kind of mad reasonableness, one is tricked into an intensely active state. . . . (10609)

Not all texts, of course, demand such an abrupt generic judgment on the part of the reader, but Hirsch's point is thereby strengthened: One of the most difficult and central acts of interpreting a text is not only the proper determination of its genre, but often the recognition that generic reflection is precisely what is needed.

As many critics have pointed out, the major thrust of Hirsch's theory is toward making authorial intention normative for the interpretation of a text, and this part of his interpretation theory has caused critics to find his concept of "reader" less than adequate. Nevertheless, his theory is important, it seems to me, especially for two reasons. First, he has made genre into a principle of meanıng: no genre, no meaning. Genre is not to be understood as an overriding generalization under which individual texts or statements are subsumed. On the contrary, the origin of any text is mixed and multiple. That is why the notion of genre is hidden at the beginning of the interpretation of any given text, according to Hirsch: "the details of the utterances are not present to consciousness all at once" (79). Yet by means of generic consideration, we come to know the range of possible fulfillments and to recognize the probable understanding toward which the conventions of the text are directed. Krieger, for example, cites the Prologue to Henry I $V$ as an instance of need for the reader to distinguish between the broad genres of history and of poetry. Read as history, the Prologue will tempt the reader to utilize one or another cause-and-effect model. Read as poetry, the Prologue will lead the reader to "transform the usual meanings of the text from the chronological to the logical" and to "follow the clues of internal relations." In short, reading the Prologue as poetry, the reader reconstructs the historical facts into "elements that are anything but random for those who have been taught to disentangle and relate them in more ways than their casual beforeness and after-ness would suggest" (156-57). 
Hirsch's second contribution consists in his classification of the process by which generic considerations lead us to anticipate the wider implications of individual texts. Through the process of discovering the intrinsic genre of a work, we become aware of the "concentrated and symbolizing conventions of the genre itself" (97). Now, Hirsch himself, in classifyıng genre as a principle of interpretation, has less regard for these "wider implications," treating them instead as provisıonal and descriptive. And so we will turn to another theorist, Hans-Georg Gadamer, for whom historicity of understanding achieves the status of a principle of interpretation.

\section{Hans-Georg Gadamer-Genre as Historicity}

Gadamer wishes to make explicit the prejudgments and foremeanings with which every interpreter comes to a text. For hım, absolute neutrality with respect to any text is an impossibility. Interpretation, on the contrary, is "the conscious assimilation of one's own foremeanings and prejudices" (238). Hirsch locates the historicity of genre in the relationship of intrinsic genre to "broader genre ideas" - which conventions, he says, are important only heuristically in arrıving at the intrinsıc genre. Gadamer-emphasizing the inescapableness of the historical-explicates how it is constitutive of the way reflection constantly understands and exercises itself.

Gadamer does this by explorıng the various modes of "being historical." The "classical," for example, lllustrates the historical process of preservation. The importance of the classical is in the fact that "its historical domain precedes all historical reflection and continues through it" (225). In other words, the classical is a foremeaning. This foremeaning is most clear in the sense we sometimes have, in reading texts or in viewing art, of being rescued from the immediate present for the sake of the enduring, the significance that can't be lost, which is understood in relation to all past and future significance as well.

When we examıne classics - those texts which "through the constant proving of themselves" set before us something we recognize as true to our own experience - we notice that they are always representatives of literary genres. Ulisses. The Rape of the Lock, the Iliad, for example, are all known to us $a$ s a novel, a mock epic, a classical epic respectıvely. In fact, classics become classıcs when, after a stylistic ideal is perceived as having been fulfilled at a certain place and tıme, we become aware of the decline and distance in subsequent works. In this sense, classics are climaxes that articulate "the hist ory of the genre in terms of before and after." Gadamer emphasizes that the climactic points of a genre usually come within a brief period of time. Although genre is therefore history-bound (much more than literary critics usually acknowledge), it is its own uprootıng. For as it endures, the classic generates an element of self-criticism" "the classical is what is preserved precisely because it signifies and interprets itself" (Gadamer 257 ). That is, the classic is not merely a statement about the past, a witness to what still needs interpretation. but is a communication with the present, a communication which overcomes its own historical distance 
From Gadamer, then, we obtain a refinement of the broad general notion of genre which Hirsch merely tolerates, namely, of its historicity. Both wish to get beyond genre as a merely historical species through which all other members are defined and to which they are subsumed. Gadamer's point is that interpretation is best understood, not so much as an act of subjectivizing as "the placing of oneself within a process of tradition, in which past and present are constantly fused" (258).

While Gadamer does clarify the historical status of genre, the heuristic function of genre in interpretation remains largely unexplored in his theory. For this, we turn to Tzvetán Todorov.

\section{Genre as a Second-Order Reality-Tzvetán Todorov}

From I odorov, we learn to differentiate genre from descriptive and explanatory accounts of the meaningfulness of texts. In his theory, genre is a "principle operative in a number of texts, rather than what is specific about each of them" (3). First of all, he posits a distance between a genre and an individual work. He insists that the notion of structure is not to be understood as referring to an empirical reality but to a model constructed according to that reality. What he helps us to understand is an epistemological issue, which tends to be overlooked in previous generic studies. That is, the structure which comes to light in a proper generic study does not claim to reproduce the experience involved in writing or in reading the book. What it does is to provide a representation, a cluster of meanıngs - a model constructed after the understanding of the reality. A model provides a context for communicatıng what goes beyond the particular constitutive meanings of a text. To go from knowledge of a genre to the structure of a given work is not to impose meaning upon the empirical reality of a text, but to incur the original process of arriving at a genre, that is, of distancing, abstracting, or generalizing from the particular. In Todorov's theory, there is no necessity that any given work embody its genre-only a probability. But we might add: If the genre has been carefully constructed there is a true probability that a text will be enhanced by being considered in the light of generic propositions.

In the long run, a genre cannot, strictly speakıng, be invalidated by a single instance. Finnegans Wake, for example, although a recognized novel, has plagued critics since it was published with respect to the way it relates to that genre. What generic considerations do admirably well is to call forth rigorous reflection on the complex factors which make individual works successful or not From Todorov, we learn to expect that the empırical reality of a particular text bears many possible relationships to the generic hypothesis which helps us to organize our response to that work. In this sense, generic considerations force us to formulate our own notion of the informing principle of texts which we might otherwise leave at the level of vague enjoyment or unexamined antipathy.

Now the distinction that Todorov makes between a description of details of individual texts and an organızıng princıple - which, precisely because it is of an order different from the empirical realıty, enables us to take distance 
from our immediate experience of the text - has important implications for the self-understanding of the reader. We turn finally to Paul Ricoeur for assistance in drawing out these implications.

\section{Paul Ricoeur-Genre as Praxis}

Ricoeur makes two important contributions to the foregoing discussion of genre. The first is his notion of genre as a means of production. In his view, genres produce discourse as a work: "to master a genre is to master a 'competence' which offers practıcal guidelines for 'performing' an individual work" (1973:135). In other words, by means of genre, the author's discourse becomes a public phenomenon. Genre keeps the author's discourse open for "fresh interpretations in new situations" (1973:137), and preserves it from distortions.

Ricoeur compares the generative function of grammar, as demonstrated by Noam Chomsky, with the generative function of literary genres: Their function "is to mediate between speaker and hearer by establishing a common dynamics capable of ruling both the production of discourse as a work of a certain kind and its interpretation according to the rules provided by the genre" (1973:136). The important point for our discussion is that the "dynamics of form" is simultaneously a "dynamics of thought." That is, the meaning-oriented content itself is produced at the same level as the corresponding principles of literary genre. The coordination of the "dynamics of form" and "dynamics of thought" can be seen in recent studies of explicitly and classically "religious" genres, such as Dominic Crossan's structural approach to parable. Differentiating story in parable from story in myth, in apologue, in action, and in satire, he relates story to "our necessary fascination with brinks and borders, with edges and limits" (Crossan: 18). More careful attention to the process of coordinating the dynamics of form and thought would seem to be needed for studies of more complex contemporary types as well.

Ricoeur's second contribution is his extension of the notion of "work" to both author and reader. For him a "work" is constituted by composition (that 1s, genre) and individual style: "Even the term 'work' reveals the nature of these new categories, which are those of production and of labor. To impose a form upon material, to subject a production to genres, and to produce an individual style are ways of considering language as a material to be worked and formed. They are the ways in which discourse becomes the object of a praxis . .." (1973:134). He concludes, "The same competence in the reader [which comes from having mastered a genre] helps him perform the corresponding operations of interpretation" (1973:135).

From Ricoeur, we are able to transpose the notion of author from one who speaks to one whose work produces something individual. By this transposition, the category of author can be seen to be as much in need of interpretation as the work produced since the author is no longer the selfevident signifier in a particular discourse. Similarly, we can transpose the notion of reader from one who listens to one whose interpretation produces 
something individual. By this transposition, the category of reader can be seen to be as much in need of interpretation as the work produced. No longer is the reader the self-evident recipient of the signifier in a particular discourse.

How might Ricoeur's notion of genre as praxis assist our understanding of a critical reader of a body of texts formally treated as a broad genre? If we apply this question to the "Catholic novel tradition," for example, we first of all notice that the classical definition of this tradition has always, implicitly at least, required the orthodoxy of the author. This requirement can best be seen in attempts - some anxious, some defiant - to exonerate authors from their unorthodox inclinations. However, among major novelists treating of cultural, doctrinal or moral matters pertinent to Catholicism are not only "native" Catholics and converts to Catholicism but also "secessionists" such as James Joyce, perhaps the most prominent innovator in the contemporary novel.

Ricoeur's notion of the reader as having the competence to master a genre allows us to reaffirm with more intelligibility than before that other than apologetic intentions can inform the studies of texts informed by Catholicism. Moreover, several problems of readership come clearly into focus: Some novels like Portratt of the Artist or Finnegans Wake have received only primitive religious readings because they have been based on the novelist's posture toward orthodox doctrine. "A Man of Scrupulous Meanness," the title of a not atypical religious interpretation of James Joyce's novels, illustrates this point. Other, more recent novels, such as Group Portrait with Lady by the Nobel prize recipient, Heinrich Böll, have received little or no assessment of their religious import. In these novels, institutional religion is regarded with irony, ritual and sacrament are seemingly impotent, and the corporate desire for a sacred edge to the everyday remains unfulfilled. The problem for the critical reader becomes one of interpreting the disillusionment or the passionate rejection of traditional religion which rejection has become a prevailing mode of enlightenment. Still other novels - those informed most straightforwardly by Catholicism, such as Kristin Lavransdatter by the Nobel prize recipient Sigrid Undset, and Graham Greene's Honorary Counsel-may offer even greater challenges to the critical reader because the revelational forces which once validated them as religious now appear to be exhausted.

Together with Ricoeur's notion of praxis, Hirsch's notion of the "multiple parentage" of intrinsic genre is highly appropos for an interpretation of the Catholic novel which would attempt to achieve both a hermeneutics of suspicion and of restoration. Todorov's distinction between informing principle and detail analysis allows us to utilize other than the orthodox model of belief to understand the thought informing the novels $/ 3 /$. Gadamer's recognition of the short life span of particular genres, too, makes it possible to enter into generic considerations with the anticipation of change rather than with a singular dread of decline. Gadamer's insistence that the rise and decline of a particular genre be part of generic study also opens the way for the notion of the dialectics of belief: on one level, the dialectics among seemingly opposed representations of belief, such as in Kristin Lavransdatter 
and Finnegans Wake; on another more basic level the dialectic between the experience of belief and its expression by the reader, which takes place in every literary transaction. On both levels, the reformulation of belief takes place within the reader according to the way the text affords a distantiation from his/her habitual beliefs.

\section{Conclusion-A New Hermeneutic Model}

We are now ready to begin to construct a model for the critical reader in the light of the preceding generic considerations. What characterizes the ideal reader? The hermeneutics of suspicion fashioned by Nietzsche, Freud and Marx, has already demythologized the notion of the reader as standing objectively disengaged from the work. Aesthetic distance has had to make room for aesthetic immanence (Lang: 133-68). But we have not had, it seems to me, a model for a reader who is both engaged with a particular work and knowledgeable of the succession of forms which can be seen to inform it.

I have tried to show that it is by means of generic consideratıons that the knowledgeable reader becomes the critical reader who is in turn capable of questioning how these forms and expressions undergo revision and mutual refinement in the text. In our study of genre, we began to see in Hirsch the notion that generic considerations are essential to a good interpretation of a text. In Gadamer, we moved to broad historical considerations, as they precede and prolong the individual text. In Todorov, we differentiated between the theoretical character of genre and the descriptive character of detail analysis. Finally, in Ricoeur, we understood genre as transforming speech into a "work," and bringing about a new notion of "reader."

To satisfy the foregoing exigencies of genre, the critical reader proceeds from naive questions about the text to critical questions of its historicity, its structure, its informing principle and finally through to the most difficult question of all - that of the reader's self-understandıng as reflected in his / her understanding of the text. We might say that the understanding of the text is refracted by means of these questions. But these refractions are held together in a new and more complex hermeneutical model (see Figure 4).

In this model, the reader's observations are expected to be more or less diffuse durıng a first reading and become progressively focused as they reach what is known in the theory of optics as the "circle of least confusion," that is, the smallest possible image. Paradoxically, this is the site at which, in a perfect lens. light comes to a point. However, the lens always has aberrations in texture and in quality, causing, for example, minute differences in the angles of refraction and subtle differences in the reflected rays of color. Although light never comes to a "perfect" point, it can be said to constıtute at that point an apex analogous, perhaps, to the irreducibly individual reader In this model, the circles are not isolated entities, such as is suggested by the traditional notion of the hermeneutical circle. Rather, in the threedimensional model, each hypothetical circle is only a part of the process of interpretation, and the individual reader is situated as the ultimately indecipherable agent of that process, both acted upon and acting. 
No longer vicious, the hermeneutical circle now signifies the essential roles of critical thought after naive reading and of informed understanding after thought. Becoming "informed" by raising generic and other questions, the reader's understanding is made capable of being continually "transformed" insofar as he/she voices the fullness of meaning always represented by the text. The challenge, then, lies with the reader whose reconstruction of the text is the condition for the possibility of its being a story that "gives life."

\section{NOTES}

11/ The adjectival form of "genre." Here I am following the usage of theorists discussed later in this paper. See the OED for the relationship between "genre" and "generate."

121 There are, of course, several "versions" of the hermeneutical circle. Perhaps the earliest is the Anselmian "Believe in order to understand; understand in order to believe," and one of the most innovative is Paul Ricoeur's early formulation, "The symbol gives rise to thought; thought is informed by symbol." A theorist's conception of the hermeneutical circle is often a touchstone to the development of his/her thought. Ricoeur, for example, in The Conflict of Interpretations, later sees the need to move away from a "too psychological" understanding of the hermeneutical circle: "For behind believing there is the primacy of the object of faith over faith; and behind understanding there is the primacy of exegesis and its method over the naive reading of the text. This means that the genuine hermeneutic circle is not psychological but methodological. It is the circle constituted by the object that regulates faith and the method that regulates understanding. There is a circle because the exegete is not his own master" (1974:389). For Hirsch, on the other hand, the hermeneutical circle is essentially the relation of the whole to parts of the text

Bernard Lonergan acknowledges that the hermeneutic circle is only "logically a circle since coming to understand is not a logical deduction " Essentially, it is a "selfcorrectıng process of learning that spirals into the meanıng of the whole by using each new part to fill out and qualify and correct the understanding reached in reading the earlier parts" (159)

Some of my colleagues, emphasizing the need for radically new perspectives, speak of the need to "break" the hermeneutic circle It remains to be seen in what sense the model I suggest at the end of this paper might represent both the self-correcting process and the need to "break" the circle

/3/ See, for example, four other models delineated recently by David Tracy the liberal, the neo-orthodox, the radical and the revisionist (22-42) 


\section{WORKS CONSULTED}

Boll, Heınrich

1973 Group Portrait with Lady New York: McGraw-Hill

Booth, Wayne

1974 A Rhetoric of Irony Chicago: University of Chicago Press.

Brandabur, Edward

1971 A Man of Scrupulous Meanness. Urbana: University of Illınois.

Christ, Carol

1976 "Storıes That Kıll and Stories That Give Life." Unpublıshed paper given at American Academy of Religıon meetıng, St. Louıs (October)

Crossan, Dominuc

1975 The Dark Interval. Toward a Theology of Story. New York Argus

Dunne, John

1967 A Search for God in Time and Memory. New York: Macmillan

Gadamer, Hans-Georg

1975 Truth and Method New York. Seabury.

Greene, Graham

1973 The Honorary Counsel New York: Simon and Schuster.

Hirsch, E. D

1967 Validity in Interpretation New Haven: Yale University Press.

Joyce, James

1916 A Portratt of the Artist as a Young Man. New York: B W. Huebsch.

1939 Finnegans Wake. New York: Viking

Krieger, Murray

1976 Theorv of Crithcism: A Tradition and Its System. Baltimore: Johns Hopkins Press

Lang, Berel

1975 Art and Inquiry Detroit. Wayne State Unıversity Press.

Lasch, Christopher

1976 "The Narcissist Society," New York Review of Books, 23 (Sept. 30), 513

Lonergan, Bernard

1972 Method in Theologv. New York: Herder and Herder.

Novak, Michael

1971 Ascent of the Mountain. Flight of the Dove New York: Harper and Row.

Orsini, G N.G

1967 "Genres," Princeton Encyclopedia of Poetry and Poetıcs. Alex Premınger, ed. Princeton: Princeton Unıversity Press, 307-09. 
Ricoeur, Paul

1973 "The Hermeneutical Function of Distanciation," Philosophy Today, 17 (Summer), 129-41.

1974 The Conflict of Interpretations. Evanston. Northwestern.

Slat off, Walter

1970 Wuth Respect to Readers. Ithaca: Cornell University Press.

Todorov, Tzvetán

1973 The Fantastic: A Structural Approach to the Lterary Genre. Cleveland: Case Western Reserve.

Tracy, David

1975 A Blessed Rage for Order. The New Pluralsm in Theology. New York: Seabury.

Undset, Sigrid

1923 Kristin Lavransdatter. New York: Alfred A. Knopf.

Wiggins, James, ed.

1975 Religion as Story. New York: Harper and Row. 


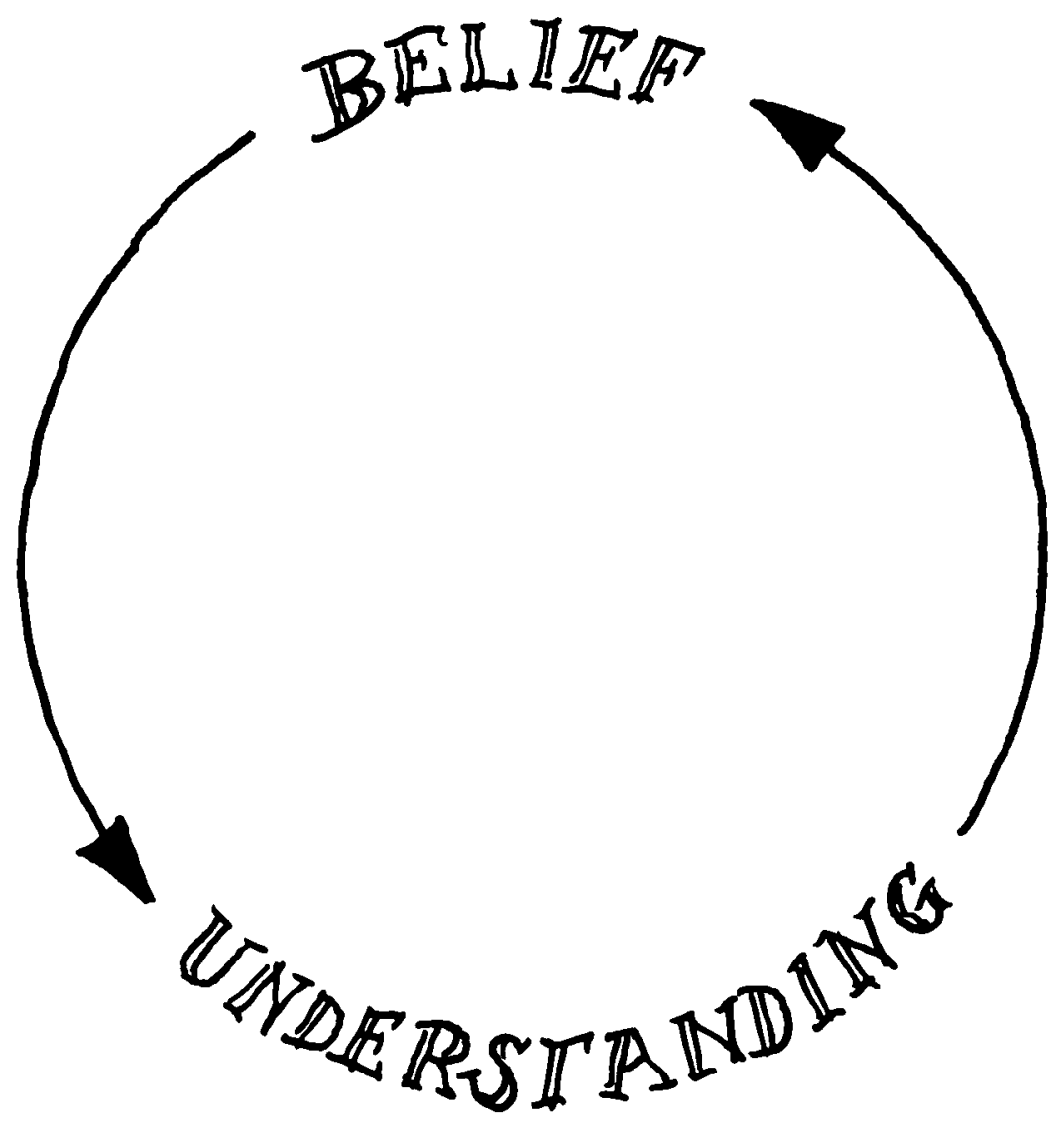

Figure 1: Traditional model of the hermeneutical circle. Ideally, understanding gives rise to belief, and belief is always informed by understanding. 


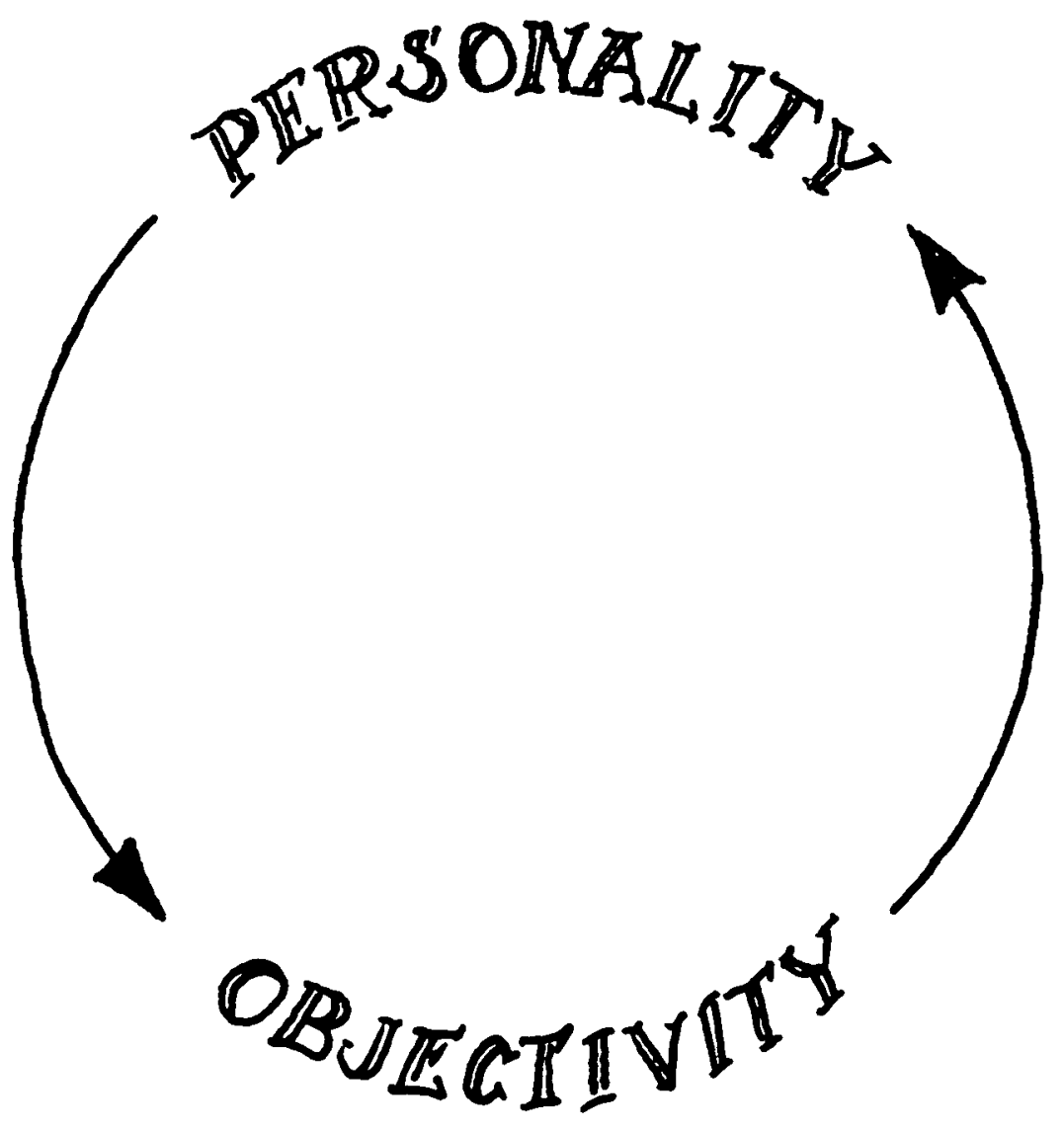

Figure 2: Krieger's notion of the hermeneutical circle. The traditional model is reduced to a vicious circle of objectıvity determıned by the changing needs of the reader's personality. 


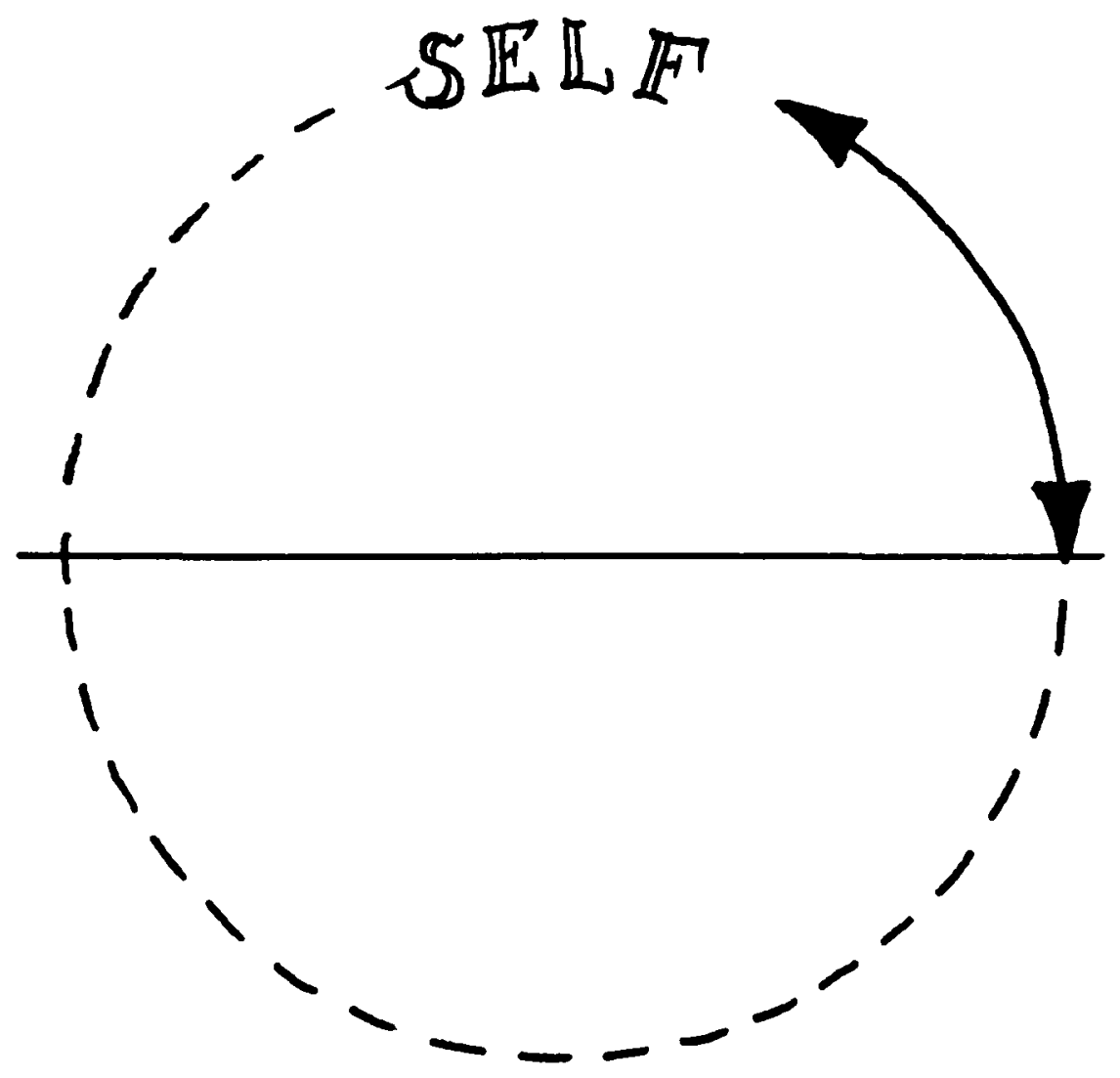

Figure 3: Lasch's notion of the hermeneutical circle. The traditional model, no longer a circle, functions instead as a mirror surface reflecting only a narcissistıc self. 


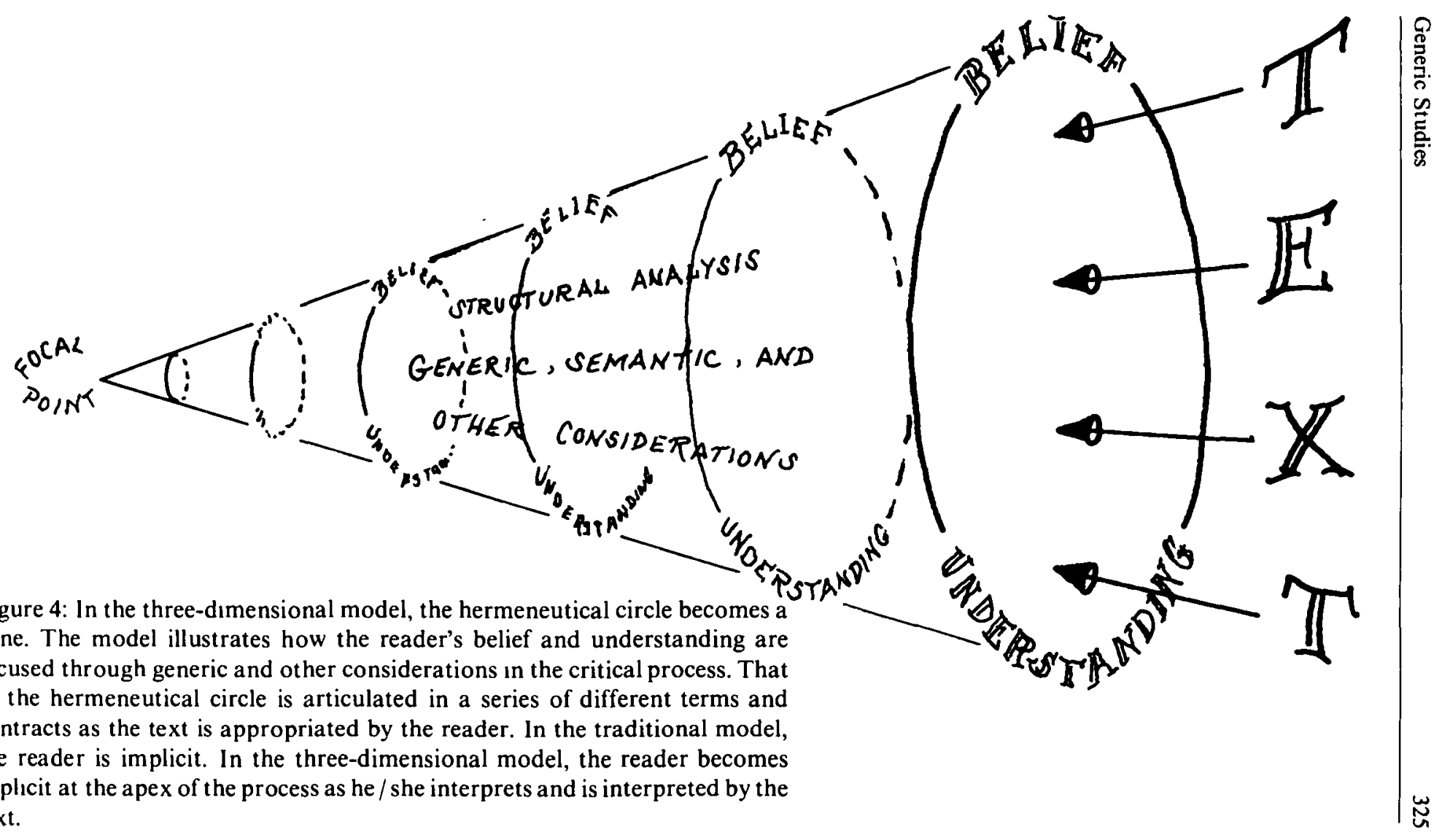

